\title{
A development cost comparison between a multi-storey mass timber and reinforced concrete building in South Africa
}

\author{
S Van der Westhuyzen, J Wium
}

High-rise timber buildings have experienced a resurgence internationally during the past two decades. This paper presents an investigation into the financial feasibility of a multi-storey mass timber building for South Africa through a development cost comparison. Two 8-storey commercial buildings - a mass timber frame and a reinforced concrete frame - were first designed by independent engineering consultants. A focus group workshop, conducted with industry professionals, assisted with the development of construction schedules. Subsequently, a financial model was developed to determine the overall development cost and financial feasibility of each option. Finally, a sensitivity analysis was conducted to investigate the effect of certain variables on the overall profitability of the mass timber frame development.

The focus group workshop identified that the construction of the reinforced concrete frame building and mass timber frame building will take 42 weeks and 21 weeks, respectively. The total capital investment required for the mass timber frame development was found to be $10 \%$ more than that of the reinforced concrete frame development (R115 691000 versus R 105118 000).

A five-year internal rate of return (IRR) of $20.9 \%$ and $25.7 \%$ was calculated for the mass timber and reinforced concrete frame developments, respectively. A significant finding of the sensitivity analysis was that the mass timber frame building proved to generate a higher fiveyear IRR than that of the reinforced concrete frame once the mass timber building achieved a rental premium of $7.8 \%$ or more. The sensitivity analysis further showed that the importation of the mass timber elements remains an expensive option, with a $16.4 \%$ five-year IRR for the imported mass timber frame (at a R17:€1 exchange rate).

\section{INTRODUCTION}

Rising awareness and interest in environmental and global warming challenges have grown significantly in recent years, leading to a call for sustainable housing technology and methods within the construction industry (UN Habitat 2016). This has sparked renewed worldwide interest in the use of timber for construction (MGA 2012). Timber remains unique as it is one of few construction materials with a negative carbon footprint before processing (MGA 2012). During its 'manufacturing period' (growth) it takes in atmospheric $\mathrm{CO}_{2}$ and releases $\mathrm{O}_{2}$ during photosynthesis. This contrasts with steel and cement which were responsible for approximately $5 \%$ (2003) and up to $7 \%$ (2002) of global greenhouse gas emissions (Anderson et al 2015). Taking this into consideration, research has shown that timber is renewable, and is the best performer across most environmental impact factors when compared to building materials such as steel and concrete, with particularly good performance in terms of greenhouse gas emissions (Crafford \& Wessels 2020; Petersen \& Solberg 2005; Sathre \& O'Connor 2010; Upton et al 2008; Wang et al 2014;

Werner \& Richter 2007).

Forte Living is a 10 -storey mass timber building in Melbourne constructed with 759 cross-laminated timber (CLT) panels. After completion it was estimated that the building has a $22 \%$ lower carbon footprint compared to similar reinforced concrete structures (Arup 2019). In light of such case studies, timber construction is promoted as a more environmentally friendly and sustainable building material when sustainable forest management is practised (as opposed to steel and concrete).
JOURNAL OF THE SOUTH AFRICAN INSTITUTION OF CIVIL ENGINEERING ISSN 1021-2019

Vol 63 No 4, December 2021, Pages 35-44, Paper 1281

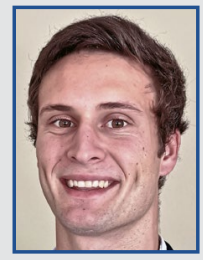

FANIE VAN DER WESTHUYZEN currently works as a structural engineer for Zutari in Cape Town. He holds a Master's in Civil Engineering from Stellenbosch University. His undergraduate thesis focused on the behaviour of South African timber species in fire. In his Master's research he went on to focus on the economic viability of a

potential multi-storey mass timber building in South Africa. He plans to specialise in timber engineering through research, and practical design and construction experience.

Contact details:

Zutari (Cape Town Office)

1 Century City Drive

Century City

Cape Town 7446

South Africa

T: +27215269400

E:fanie.vdw@zutari.com

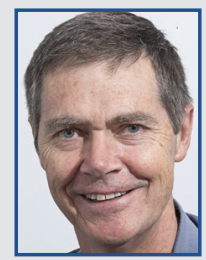

PROF JAN WIUM (FSAICE) holds a PhD from the Swiss Federal Institute of Technology in Lausanne. He worked in industry as a structural engineering consultant and project manager for 20 years. In 2003 he joined Stellenbosch University as specialist in structural concrete and structural dynamics. Since 2010 he is responsible for the focus area in Construction Engineering and Management at the Department of Civil Engineering. His research interests are modular construction, collaboration for improved constructability, design management, and risk management.

\section{Contact details:}

Department of Civil Engineering

Stellenbosch University

Private Bag X1

Matieland 7602

South Africa

T: +27218084348

E: janw@sun.ac.za 
As a result, high-rise timber buildings have experienced a resurgence internationally during the past decade. Approximately 20 mass timber buildings, which are six storeys and higher, have been completed since 2010, while in 2017 more than 13 multi-storey mass timber buildings (seven storeys and higher) were under way (Forestry Innovation Investment 2017; Salvadori 2017). The growth in the market share of multistorey mass timber building has sparked interest among South African property developers, and architecture, engineering and construction (AEC) professionals. Questions have arisen - upon completion of previous research on mass timber elements by the authors - regarding the potential development cost of multi-storey mass timber buildings and how this would compare to a typical building system used in South Africa. The new-found interest in timber construction among South African industry professionals merits research in mass timber construction (MTC). It would be of interest to see how the application of mass timber compares to that of reinforced concrete, since reinforced concrete is the most dominant construction material used in South Africa (Drennan 2017). Previous studies internationally have made comparisons between timber and conventional construction options, but no such comparison has been made for the South African industry (MGA 2012; Smith et al 2018; Timber Development Association NSW 2015).

This paper presents a development cost comparison between a multi-storey mass timber and a reinforced concrete building in South Africa. The aim is to assess the feasibility of using mass timber in multistorey structures in South Africa.

\section{DESIGNS}

\section{Conceptual designs and design loads}

The building considered for the study is a fictitious 8-storey upmarket commercial building situated in the Sandton central business district (CBD). The building footprint is $2430 \mathrm{~m}^{2}$ with a gross floor area (GFA) of $5472 \mathrm{~m}^{2}$ for the eight storeys (excluding lift and stair shaft area). The floor-to-floor height is $3.5 \mathrm{~m}$ throughout the building, resulting in a total height of $28 \mathrm{~m}$. The building has a $66 \mathrm{~m}^{2}$ column grid from floors 1 to 8 as seen in Figure 1 . The external face of the building is covered

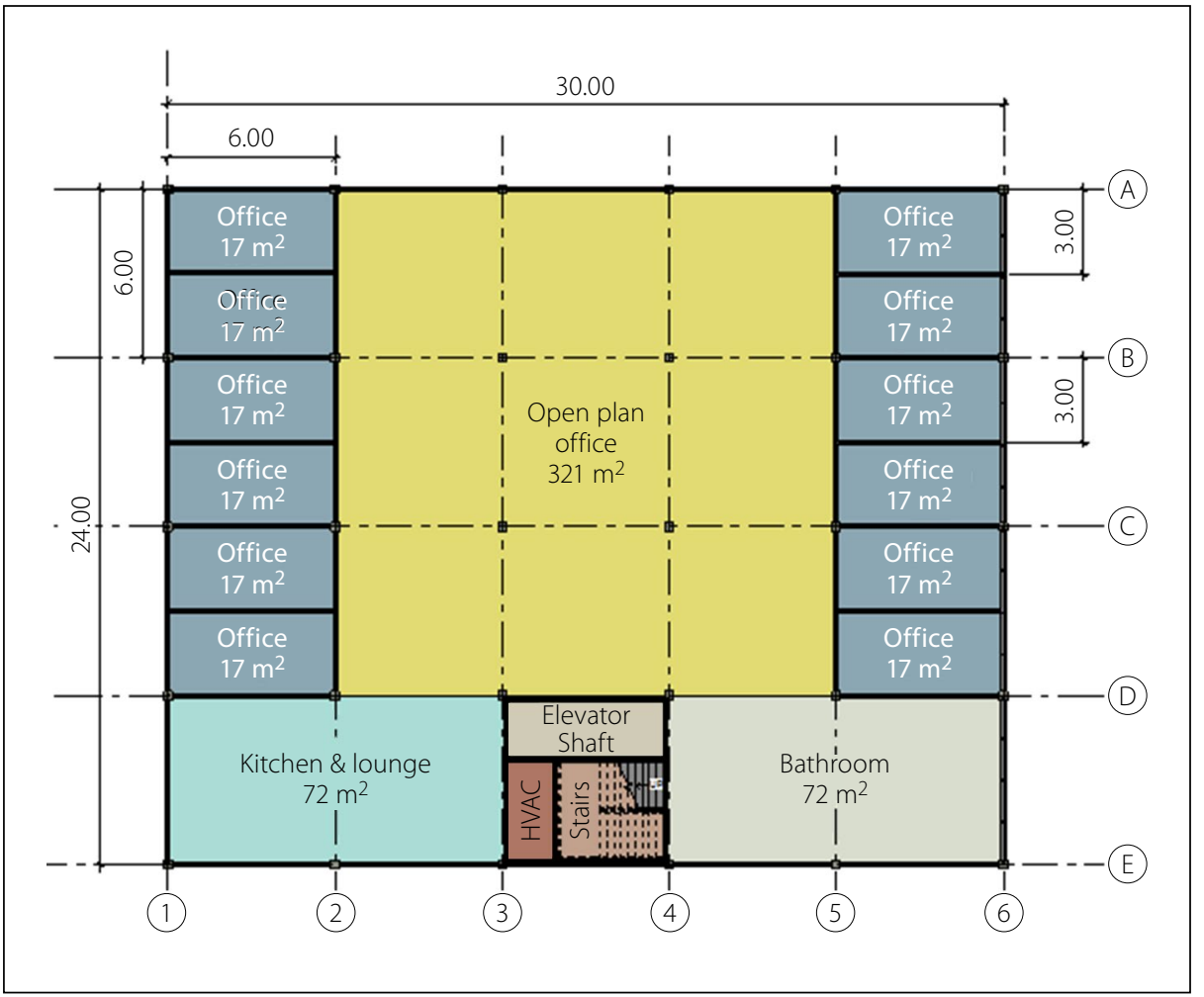

Figure 1 Floor plan for building

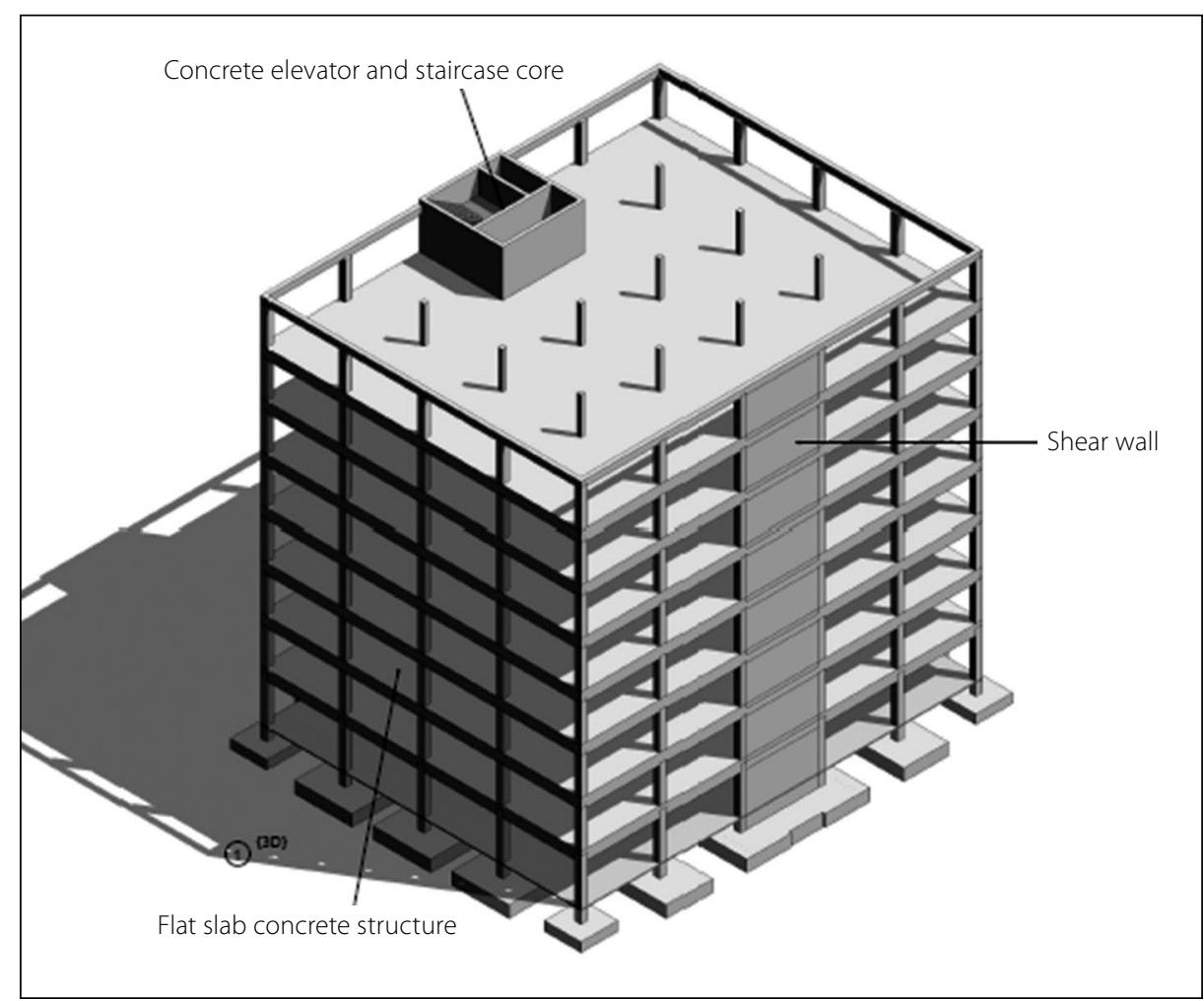

Figure 2 3D Revit (Autodesk 2019) model of concrete frame

by an aluminium glass façade, while lightweight in-fill drywalls make up the office partitions. The timber and concrete buildings share the same basic layout for comparison purposes.

\section{Design loads and limit states}

The buildings in this study were conceptually designed by independent structural engineering firms. SANS 10160-2 (SANS
2011) was applied to both structures. The reinforced concrete building was designed using SANS 10100-1 (SANS 2000), whereas the mass timber frame building was designed using Eurocode 5 (EN 2004). This is largely ascribed to the European consulting firm's familiarity with Eurocode 5 (EN 2004) and a lack of information about CLT in SANS 10163-1 (SANS 2003). Both designs remain conceptual and are 
Table 1 Summary of concrete structure

\begin{tabular}{|c|c|c|c|c|c|}
\hline Element & Location & Depth (m) & Width (m) & Length (m) & Quantity (no) \\
\hline \multirow{5}{*}{ Footings (30 MPa) } & Inner & 0.8 & 5.1 & 5.1 & 10 \\
\hline & Outer & 0.7 & 3.2 & 4.1 & 10 \\
\hline & Corner & 0.6 & 3.0 & 3.0 & 4 \\
\hline & Shear wall & 0.8 & 4.0 & 8.0 & 1 \\
\hline & Core & 0.8 & 10.0 & 10.0 & 1 \\
\hline \multirow{3}{*}{ Inner columns } & $1-2$ & 0.5 & 0.5 & 3.5 & 20 \\
\hline & $3-5$ & 0.4 & 0.4 & 3.5 & 20 \\
\hline & $6-8$ & 0.3 & 0.3 & 3.5 & 20 \\
\hline Outer columns & $G-8$ & 0.5 & 0.5 & 3.5 & 16 \\
\hline \multirow{2}{*}{ Slab (35 MPa) } & Surface bed & 0.12 & 24 & 30 & 1 \\
\hline & Flat slab 1-8 & 0.3 & 24 & 30 & 7 \\
\hline Ring beam & 2-Roof & 0.5 & 0.3 & 108 & 8 \\
\hline \multirow{2}{*}{ Walls } & Core & 0.25 & 33.8 & 3.5 & 8 \\
\hline & Shear & 0.25 & 5.5 & 3 & 8 \\
\hline
\end{tabular}

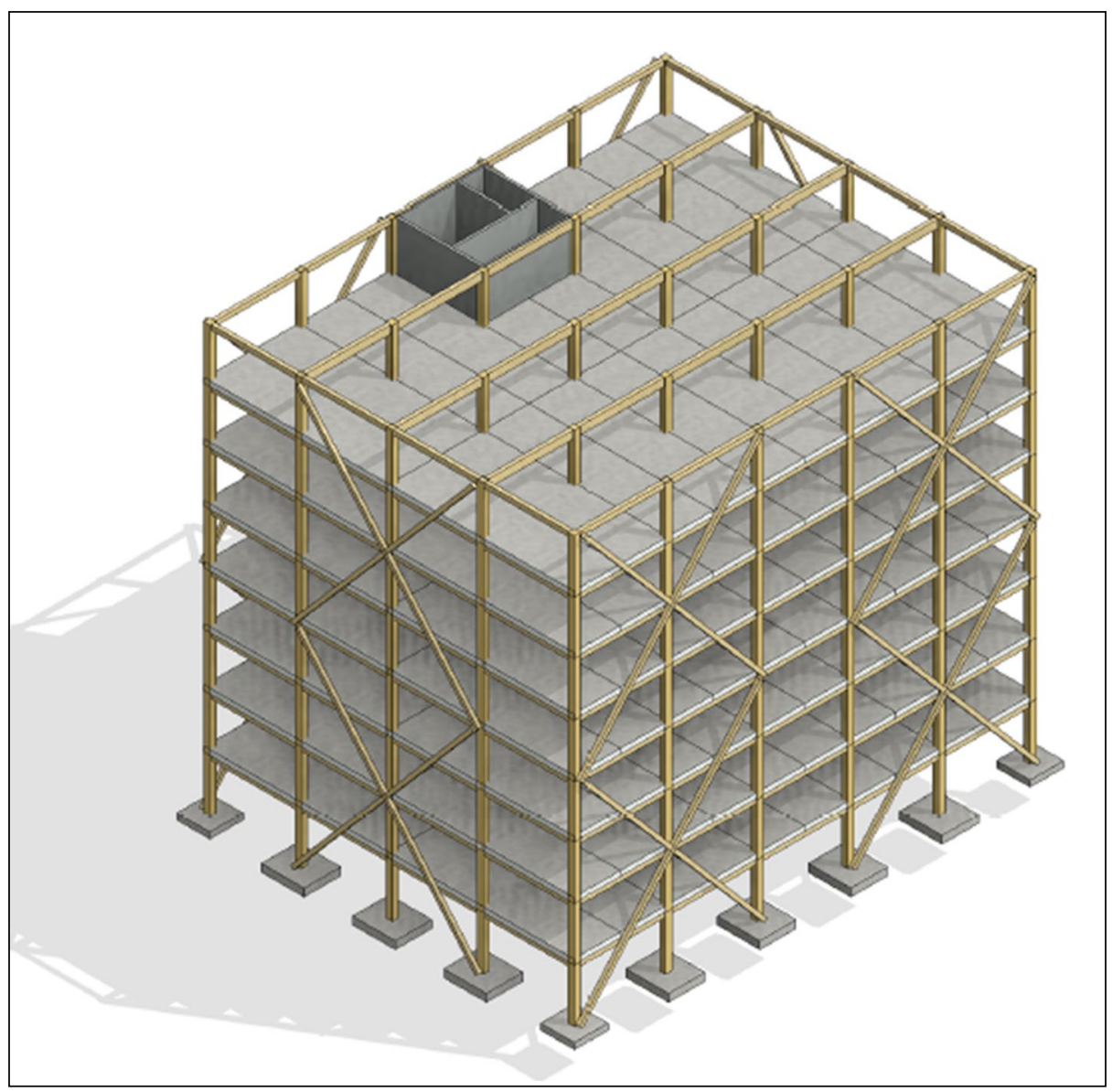

Figure 3 3D Revit (Autodesk 2019) model of mass timber frame

considered to be conservative (have not been optimised).

\section{Reinforced concrete frame building}

The structural analysis and design of the reinforced concrete building was performed by an independent consulting engineering firm in South Africa. Figure 2 is the system of choice for this particular design. Research by Drennan (2017) has shown that a post-tensioned slab is a cheaper alternative for concrete slabs (especially in the case of long-spanning slabs). However, normal reinforced concrete remains the most common building technique in South Africa. As such, and due to the $66 \mathrm{~m}^{2}$ column grid, it was decided to simplify the design by selecting normal reinforced concrete. Table 1 provides a summary of the dimensions of the main concrete elements within the building. Upon a design review it was realised that a raft foundation may have been more appropriate, given the large dimensions of the footings (resulting from the low safe bearing pressure chosen).

\section{Mass timber frame building}

For this structural option a realistic timber building for South African conditions was envisaged. It takes into account the timber products that are currently manufactured in South Africa, as well as the skills and expertise of the carpenters/contractors as raised during the focus group workshop (discussed further down in the section titled "Focus group participants" on page 38). As such, the design can be considered conservative (as in the case of the concrete structure). The structural analysis and design of the building were performed by an independent consulting engineering firm (located in the Czech Republic) with previous experience of mass timber frame structures. Figure 3 is an image of the 3D Revit (Autodesk 2019) model of the proposed mass timber structure.

A column-beam system with a CLT core and lateral glulam bracing is the system of choice for the timber building. One-way spanning, $220 \mathrm{~mm}$ deep CLT floor panels span between large glulam beams as seen in Figure 4. Each CLT floor panel consists of seven layers (30-30-30-40-30-30-30) and is $6 \mathrm{~m}$ long and $3 \mathrm{~m}$ wide, with a total estimated mass of 1.86 tons per panel. The CLT panels are single span, simply supported on glulam beams (see Figure 4).

The structure of the proposed floor system is illustrated in Figure 5. A $50 \mathrm{~mm}$ screed layer protects the CLT from moisture damage and assists with vibration control. Additional sound insulation, separation membranes and sealing tapes are also recommended to ensure the floor system satisfies the necessary design requirements. 
The floor system was designed using Stora Enso's Calculatis software (Stora Enso 2019).

Initially, all the glulam beams and columns were designed as GL24h timber (imported timber). However, in the description below, South African timber species such as SA pine and saligna (eucalyptus) are considered. Varying dimensions with different timber species were therefore scrutinised by the authors in an attempt to optimise the cost of the structure. These options are discussed further down in the section titled "Development cost" (see page 40). The design completed by the Czech consultant only considered the use of GL24h timber. Alternative conceptual designs using South African timber species were verified by the authors through calculations and structural analysis software. The design completed by the Czech consultant for GL24h timber is presented in Table 2.

The mass of the reinforced concrete frame building is approximately 3.6 times more than the mass timber frame option. As a result, the use of mass timber as opposed to conventional reinforced concrete for the structural frame resulted in a $68 \%$ reduction in foundation size from the concrete building for this particular comparison.

\section{Connection design}

Beam-column and column-column connections in the timber frame were modelled as fixed connections in the structural model as per recommendation from the Czech consultant. The beam column connection experienced a maximum shear force of $136 \mathrm{kN}$ and maximum bending moment of $150 \mathrm{kNm}$. Figure 6 shows a 3D render of a proposed connection to resist such forces. A steel-plate-and-dowel system was recommended by the Czech consultant. An international supplier of mass timber connections provided additional assistance with the design and costing of the steel connections, membranes, taping and sound-proofing. The impact of less expensive hinged connections on the cost and beam element size was not considered and is a subject for further refinement.

\section{Timber rational fire design}

A rational fire design was performed by the Czech consultant, where the timber was initially assumed to be GL24h. Subsequently, a rational fire design was performed by the authors using S7 SA

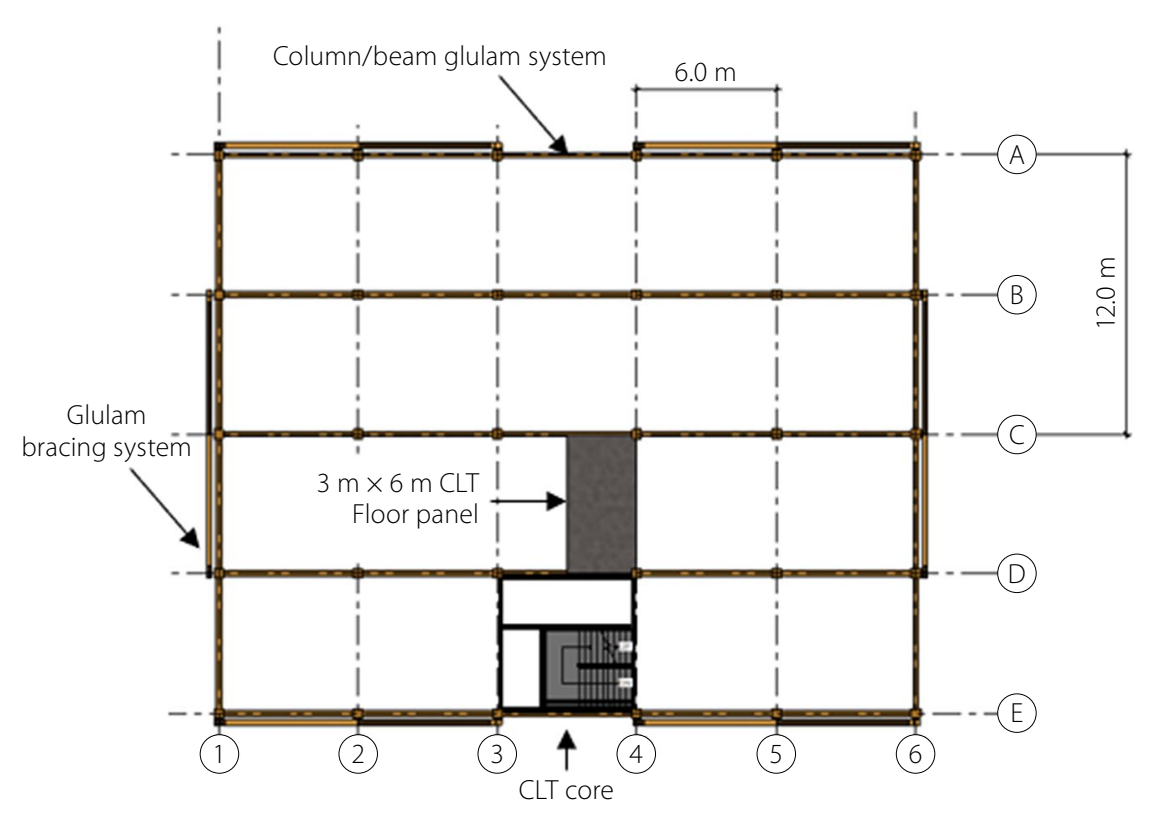

Figure 4 Plan view of the mass timber building

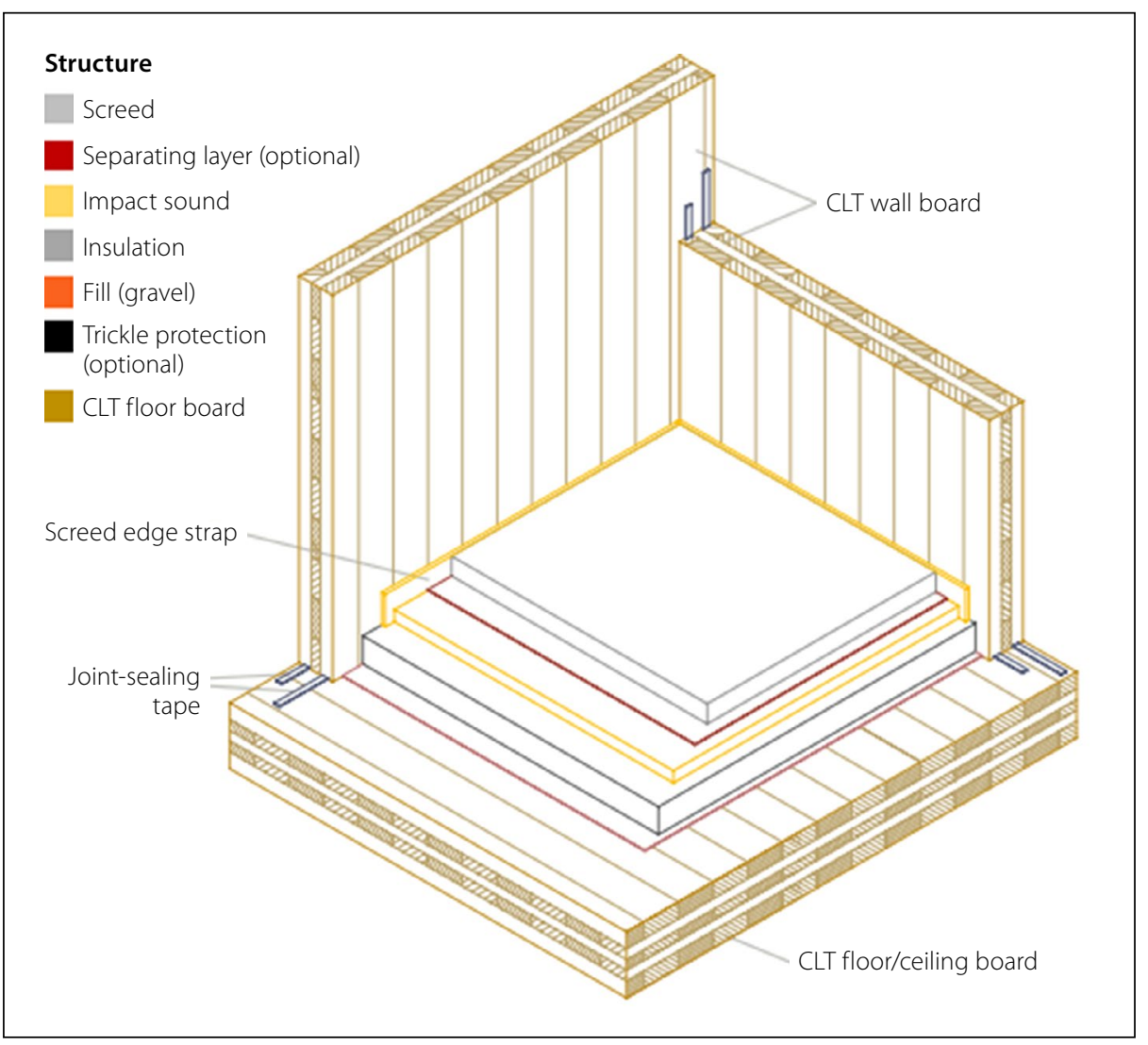

Figure 5 Proposed CLT floor system (Stora Enso 2015)

pine and S10 SA pine. As such, different cross-sectional dimensions are required to those presented in Table 2. Eurocode 5 (EN 2004) was used throughout the entire fire design procedure. The reduced crosssection method was applied for both the glulam beams and columns. The mass timber structure satisfies the necessary ultimate limit state (ULS), serviceability limit state (SLS), and fire limit state requirements (FLS).

\section{CONSTRUCTION SCHEDULE}

\section{Focus group participants}

With the purpose of establishing a construction schedule, five industry professionals participated in a focus group workshop together with the authors. Each one of these participants practises in a different area of expertise and hence made valuable contributions. Table 3 provides information regarding the profession, 
Table 2 Summary of mass timber frame for GL24h

\begin{tabular}{|l|c|c|c|c|c|}
\hline \multicolumn{1}{|c|}{ Element } & Location & Depth (m) & Width (m) & Length (m) & Quantity (no) \\
\hline & Inner & 0.6 & 3.2 & 3.2 & 10 \\
\hline Footings (30 MPa) & Outer & 0.5 & 2.4 & 2.8 & 10 \\
\hline & Corner & 0.4 & 2.2 & 2.2 & 1 \\
\hline Columns (GL24h) & Core & 0.5 & 8 & 8 & 240 \\
\hline Internal beams (GL24h) & $1-8$ & 0.4 & 3.5 & 120 \\
\hline Ring beam (GL24h) & $1-8$ & 0.52 & 0.24 & 6 & 144 \\
\hline Bracing beams (GL24h) & $1-8$ & 0.32 & 0.24 & 6 & 24 \\
\hline CLT floors (220L75-2) & $1-8$ & 0.26 & 0.24 & 18.32 & 126 \\
\hline CLT floors (220L75-2) & $1-8$ & 0.22 & 3 & 6 & 14 \\
\hline CLT core (180 C35) & $1-8$ & 28 & 3 & 32.08 & 1 \\
\hline
\end{tabular}

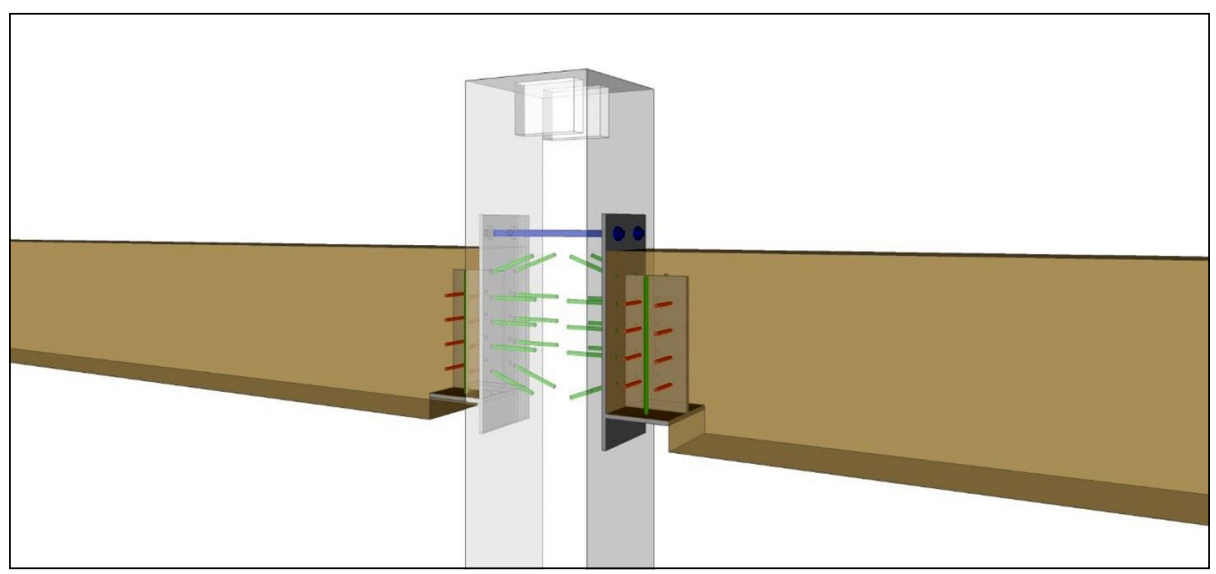

Figure 6 Potential beam-column connection used in timber frame

qualification, experience and position of each participant.

A week before the workshop commenced each focus group participant was provided with the $3 \mathrm{D}$ conceptual models of the buildings, as well as additional information regarding multistorey mass timber construction. The participants were required to complete individual construction schedules for the mass timber and reinforced concrete frame building, respectively. On the day of the workshop a number of assumptions which may have been unclear were first discussed and clarified. Following this, the construction schedule and Gantt charts of each participant were presented and discussed. Finally, a combined construction schedule was developed for the mass timber and reinforced concrete frame buildings.

\section{Assumptions}

The following assumptions were made during the workshop:

- A single fixed crane would be required for both the concrete and timber building.

\section{Table 3 Focus group participants}

\begin{tabular}{|l|l|l|l|}
\hline \multicolumn{1}{|c|}{ Profession } & \multicolumn{1}{c|}{ Qualification } & Experience & Company position \\
\hline Project Manager & BEng (Civil) & 38 years & Managing Director \\
\hline Project Manager & BSC (Building Management) & 30 years & Managing Director \\
\hline $\begin{array}{l}\text { Contractor } \\
\text { Carpenter } \\
\text { Glulam Manufacturer }\end{array}$ & BSc (Building) & 21 years & Contracts Director \\
\hline $\begin{array}{l}\text { Carpenter } \\
\text { CLT Manufacturer }\end{array}$ & $\begin{array}{l}\text { Bachelor of Architecture Studies } \\
\text { (B.A.S) }\end{array}$ & 23 years & Owner \\
\hline
\end{tabular}

The construction schedule for both buildings would incorporate finishes.

- A five-day work week, from Monday to Friday, would apply.

- Concrete for the slabs and beams was to be pumped, whereas the verticals (columns, shear walls and core) would be cast with buckets.

- A power float finish would be applied to the reinforced concrete slab.

- A prefabricated, deliver-and-build construction technique would be applied. As such, excessive amounts of timber elements would not be stored on-site. The timber elements would be cut and shaped off-site.

- It was assumed that the South African multi-storey mass timber building industry is an established industry. Artisans would thus be familiar with the construction technique, and manufacturers would be capable of supplying material regularly and on time.

- It was assumed that the construction schedule remains unaffected whether the timber components are imported or locally manufactured.

- Internal finishes were all installed onsite, despite the fact that services could be pre-installed in the factory for CLT elements.

\section{Reinforced concrete frame schedule}

It was assumed that construction would start on 6 January 2020. Figures 7 and 8 show timelines of the main tasks scheduled for construction of the concrete and timber structures, respectively. Concrete work finished on 25 September 2020, while internal finishes for all floors were completed on 20 October 2020 - approximately four weeks later. Overall, the total estimated time required to finish the building frame and internal finishes was 207 working days (approximately 42 weeks or 10 months).

\section{Mass timber frame schedule}

The time to construct the foundations and building substructure was assumed to be the same for both buildings for the purpose of this analysis, as can be seen in Figures 7 and 8 . The mass timber frame was constructed significantly faster than the reinforced concrete frame. A five-day per floor turnaround time was deemed realistic for the timber building as opposed to the 15 days allocated for concrete. A total of 40 working days was required to construct the entire timber frame. A 20-day fit-out time per floor was also 


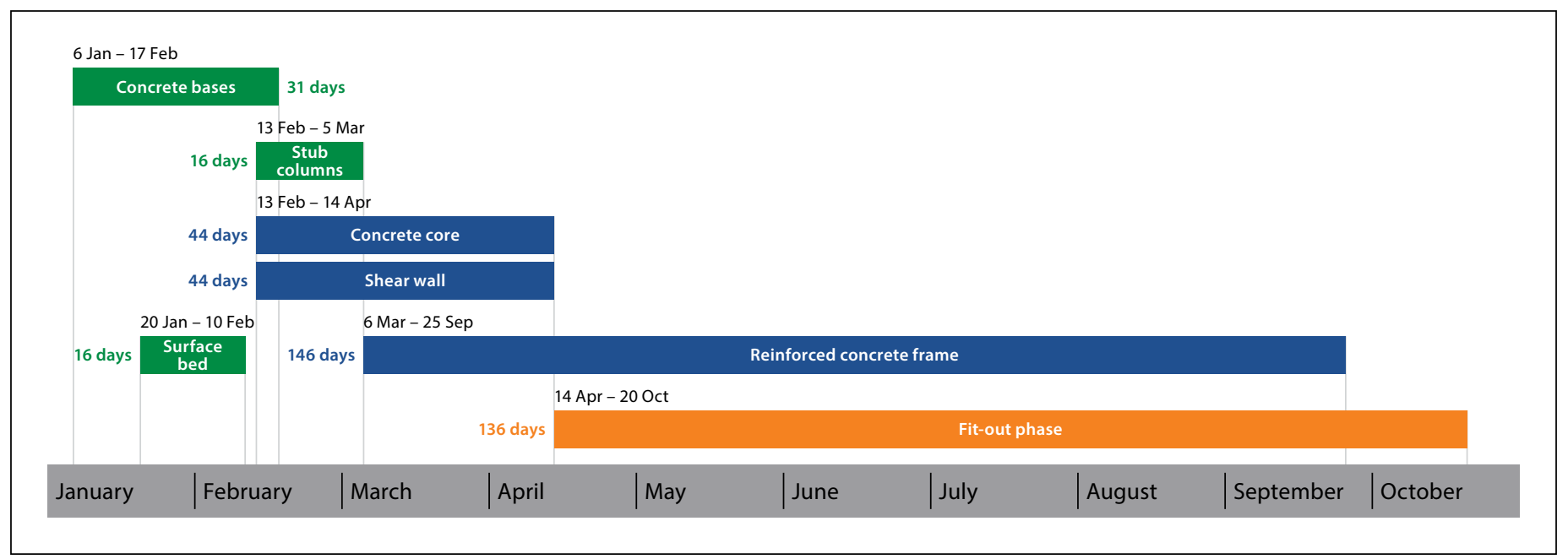

Figure 7 Timeline of reinforced concrete structure

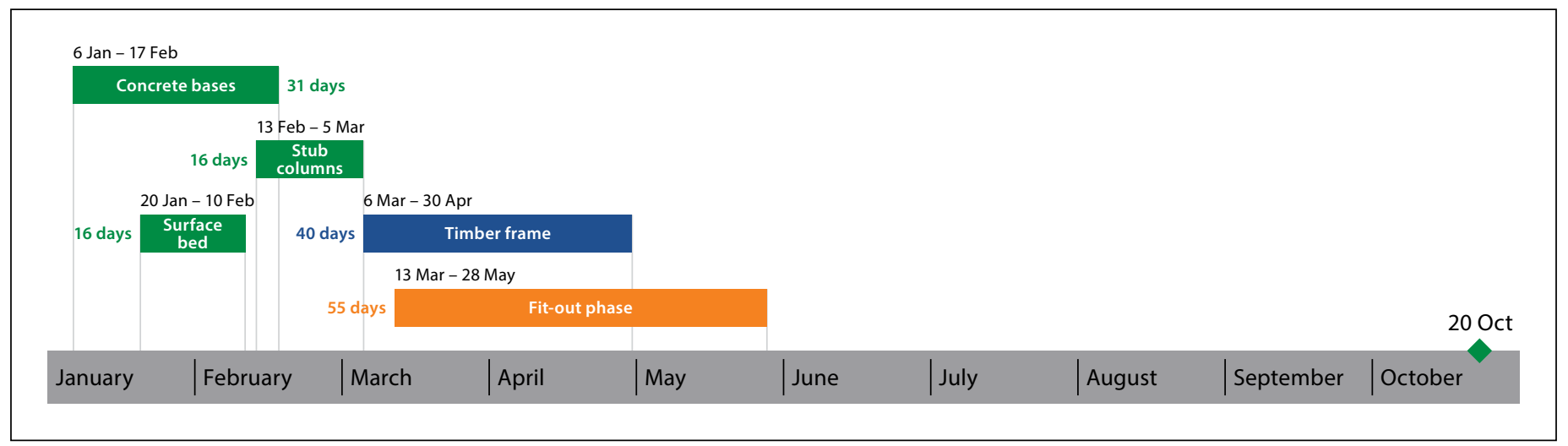

Figure 8 Timeline of mass timber structure

allocated for both buildings. The focus group saw this as a conservative estimate as CLT panels allow for the pre-installation of services off-site. The entire timber structure, including internal finishes, was estimated to be constructed in 104 working days (approximately 21 weeks or 5 months). This was five months earlier than the reinforced concrete frame, translating to a 50\% reduction in construction schedule. The focus group noted that the true benefit of mass timber construction comes from early access for follow-on trades (fit-out). This is highlighted in Figures 7 and 8, where a total fit-out time of 136 days was required for the reinforced concrete frame building, whereas only 55 days were required for the mass timber frame building.

\section{DEVELOPMENT COST}

Several stakeholders assisted in the costing of the two buildings. Two professional quantity surveyors were involved throughout the costing process. Various manufacturers were contacted to assist in the costing of the mass timber frame building due to a lack of established multi-storey mass timber projects in South Africa.
These manufacturers included CLT manufacturers, glulam manufacturers, steel connection suppliers, custom steel part manufacturers, and international suppliers.

\section{Procurement of timber}

Different options were investigated for the procurement of mass timber elements, as shown in Table 4. The first three columns with timber alternatives consider manufacturing the glulam elements locally in South Africa using different timber species and grades. The final column presents the estimated cost of importing the timber elements from Europe, which is dependent on the Rand-Euro exchange rate. The dimensions of the timber elements vary according to the grade and species of timber specified in the design. Calculations were performed to determine equivalent cross-sectional dimensions based on similar ultimate bending resistances (approximately $161 \mathrm{kNm}$ ) for the different grades and species of the beams. A similar comparison was made for the glulam columns based on similar ultimate compressive resistances (2 $150 \mathrm{kN})$.

An aspect which demands consideration is the availability of a specific timber grade for a given timber species. S5 and S7 SA pine is generally available from South African sawmills, whereas S10 SA pine is difficult to obtain. Manufacturers therefore resort to using saligna (eucalyptus) - a more expensive hardwood species - to manufacture S10 glulam beams. Table 4 presents the cost per running metre of beam/column for the different options. Discussions with manufacturers indicated that it costs approximately R12 000/m 3 of S7 SA pine to manufacture glulam or CLT (Holzbau Carpentry Hess CC 2020; XLAM South Africa (Pty) Ltd 2020). The lack of S10 SA pine availability presents a challenge in determining a realistic cost per cubic metre of manufacturing glulam. A $20 \%$ premium has been added to the $\mathrm{S} 7$ price for comparison purposes based on discussions with local suppliers (Holzbau Carpentry Hess CC 2020; XLAM South Africa (Pty) Ltd 2020). S10 SA pine is, however, not considered in the final Bill of Quantities due to a lack of availability and uncertainty surrounding the cost per cubic metre.

Given the above information and the assumptions that were made, S7 SA pine and S10 SA pine are the two most 
Table 4 Cost per metre comparison for timber beams and columns

\begin{tabular}{|c|c|c|c|c|}
\hline Description & S7 SA pine & S10 SA pine & S10 saligna & GL24h spruce \\
\hline \multicolumn{5}{|l|}{ Beams } \\
\hline Dimension (mm) & $630 \times 240$ & $520 \times 240$ & $520 \times 240$ & $520 \times 240$ \\
\hline Cost $/ \mathrm{m}^{3}$ & R12 000 & $\mathrm{R} 14400^{\mathrm{a}}$ & R17 000 & $\mathrm{R} 15863^{b}$ \\
\hline Cost per m & R1 815 & R1 797 & R2 122 & R1 980 excl treatment \\
\hline \multicolumn{5}{|l|}{ Columns } \\
\hline Dimensions (mm) & $394 \times 394$ & $368 \times 368$ & $368 \times 368$ & $380 \times 380$ \\
\hline Cost $/ \mathrm{m}^{3}$ & R12 000 & $\mathrm{R} 14400^{\mathrm{a}}$ & R17 000 & $\mathrm{R} 15863^{b}$ \\
\hline Cost per m & R1 863 & R1 950 & R2 302 & R2 291 excl treatment \\
\hline \multicolumn{5}{|c|}{$\begin{array}{l}\text { Transportation cost of beams included in price estimate } \\
\text { a Assumed a } 20 \% \text { premium on the cost of S7 SA pine. } \\
\text { b R17:€1 Euro exchange rate; includes customs and import taxes, transportation and commission }\end{array}$} \\
\hline
\end{tabular}

\section{Table 5 CLT comparison}

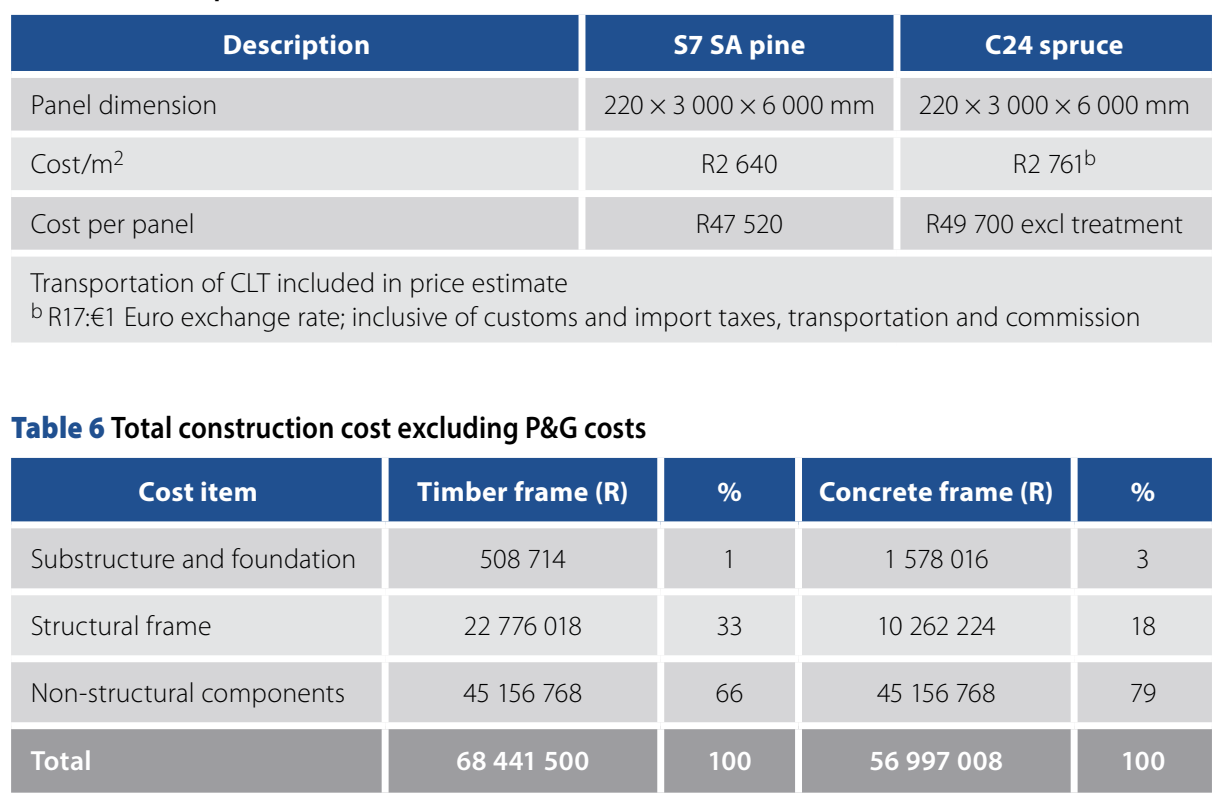

cost-effective solutions for the glulam beams and columns in the mass timber frame building. S10 SA pine beams could potentially work out to be the most cost-effective solution given the R14 400/ $\mathrm{m}^{3}$ assumption. S10 saligna and GL24h spruce remain the two most expensive options for this analysis.

The cost of glulam imported from Europe (also known as BSH) was approximately $€ 630 / \mathrm{m}^{3}$ for untreated spruce. Guided by industry professionals from a local timber supplier, the total price (including shipping) for the untreated spruce equated to $\mathrm{R} 15863 / \mathrm{m}^{3}$, at an exchange rate of R17:€1. Analysis of the Rand-Euro exchange rate showed that any rate below R12.6:€1 (which is unlikely) could make importation of untreated spruce the most cost-effective solution.

Timber elements within buildings found in coastal zones require treatment as specified by building regulations in South particular multi-storey mass timber building in order to avoid potential delays. The production of such high volumes of mass timber may prove to be a significant challenge for local manufacturers due to limited available production lines. As a result, importation of timber becomes a more viable option, despite the additional associated cost. Investment into the upgrading/ upscaling of machinery in the sector will inevitably alleviate the challenge regarding manufacturing. A fictitious situation was thus assumed where large mass timber products can be manufactured within SA.

Table 5 summarises the results of the investigation for different CLT procurement options. Upon investigation it was found that the mechanical performance of S7 SA pine CLT requires testing to determine how its mechanical properties compare to those of C24 spruce CLT. It was assumed that the mechanical properties were approximately equivalent in order to perform the cost analysis. The price of $220 \mathrm{~mm}$ thick untreated C24 spruce is approximately $€ 110 / \mathrm{m}^{2}$ depending on the European supplier. Guided by industry professionals from a local timber supplier, the total price (including shipping) of the CLT from untreated spruce equated to R2 761/m², at an exchange rate of R17:€1. The price for producing CLT from S7 SA

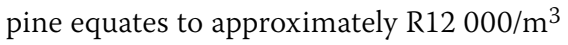
which is equivalent to $\mathrm{R} 2640 / \mathrm{m}^{2}$ for a $220 \mathrm{~mm}$ thick panel. From Table 5 it is evident that the S7 SA pine CLT is a more cost-effective alternative to importing CLT from Europe, given the above assumptions.

Africa, i.e. SANS 10005 (SANS 2020). The proposed mass timber structure is assumed to be located within the Sandton CBD which is located outside the coastal zone. As such, it does not require additional treatment. However, timber will require treatment if the building were located within one of South Africa's coastal cities, with an associated increase in the overall cost of the mass timber elements.

Interviews with manufacturing professionals indicated that current manufacturing limitations within South Africa prevent the large-scale production of large crosssectional beams/columns typically required in multi-storey mass timber structures. The current conceptual design contains approximately $1600 \mathrm{~m}^{3}$ of mass timber which will need to be manufactured over a 70-day construction period. This translates into approximately $23 \mathrm{~m}^{3}$ of mass timber to be manufactured on a daily basis for this

\section{Total construction cost}

The total construction cost is summarised in Table 6. The R11 445000 difference in total construction cost translates into a $20 \%$ increase in construction cost from the reinforced concrete frame building.

Table 7 contains the total construction cost including the $P \& G$ cost, contractor contingencies and contract escalations as per standard industry practice. Total costs of R75 638000 and R65 311000 were calculated for the mass timber and reinforced concrete frame buildings, respectively. The mass timber frame building is R10 327000 more expensive than the concrete frame building with regard to total construction cost.

\section{Total capital investment}

A well-established property development firm assisted in developing a financial model 
to determine the overall development cost and financial feasibility of the ventures. Capital cost items such as land costs, construction costs, professional fees, marketing costs and general costs (which include interest during construction) were accounted for in the model. Overall, the total capital investment required for the mass timber frame building is R115 691000 . This is R10 573000 more than the R105 118000 total capital investment required for the reinforced concrete frame building, which translates into a $10 \%$ increase.

\section{Earlier return on investment}

The current monthly rental fee for green certified office spaces in the Sandton CBD is approximately $\mathrm{R} 150$ per $\mathrm{m}^{2}$ whereas in the Cape Town CBD the rental is closer to R165 per $\mathrm{m}^{2}$ (Abland 2020). On-grade parking bays hold a further opportunity to earn an income from the development. Table 8 shows that the total monthly income for the development is R929 300 based on a $100 \%$ occupation Sandton CBD office rental fee and on-grade parking. This results in a R4 646500 income over the five months while the reinforced concrete frame building is still under construction. The effect of an earlier return on investment is presented below under the heading "Internal rate on return" and is quantified by calculating the internal rate of return of each development. Discussions by the authors revealed that a $100 \%$ occupation for both buildings may be optimistic. A sensitivity analysis on the occupation rate should therefore be conducted for future studies.

\section{Interest during construction}

Developments are typically funded through equity provided by the developer or private investors and a development loan obtained from an accredited credit provider (Abland 2020). A 70:30 debt to equity ratio was assumed for this particular development. Money is drawn from the development loan once equity is exhausted (Abland 2020). An interest rate of $8 \%$ per annum was assumed for this particular project. Proportions for monthly expenditure were applied based on the experience of the developer and allowed for the development of an 'S-curve' for both buildings (Figure 9). The rate at which equity was utilised and money drawn from the development loan was therefore determined. Equity of R14 370000 and R3 796000 was calculated after subtracting R19 152000 equity in respect of land value (based on the 70:30 debt to equity ratio) for

Table 7 Total construction cost including P\&G cost

\begin{tabular}{|l|c|c|}
\hline \multicolumn{1}{|c|}{ Cost item } & Mass timber frame (R) & Concrete frame (R) \\
\hline Total construction cost & 68441500 & 56997008 \\
\hline Preliminary and general cost & 4619801 & 5699701 \\
\hline Contingencies (2.5\%) & 1826533 & 1567418 \\
\hline Pre-contract escalation (1.5\%) & 280829 & 240990 \\
\hline Contract escalation (1.5\%) & 469804 & 806314 \\
\hline Total & 75638467 & 65311431 \\
\hline
\end{tabular}

Table 8 Monthly return on investment

\begin{tabular}{|l|c|c|c|}
\hline Income description & Rate & Area / number of bays & Monthly income \\
\hline Gross rentable area & R150/m² & 5427 & R820 800 \\
\hline On-grade parking & R500/bay & 217 & R108 500 \\
\hline Monthly net rental & & & R929 300 \\
\hline
\end{tabular}

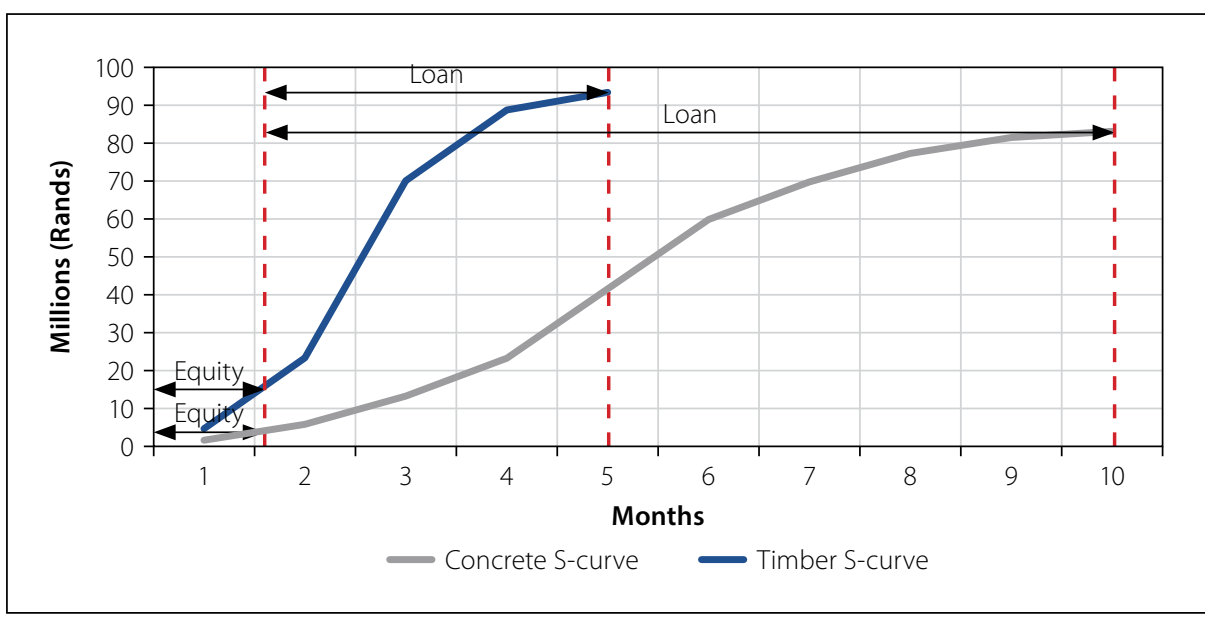

Figure 9 Cumulative cash outflow during construction

the timber frame and reinforced concrete frame buildings, respectively.

Figure 9 shows the expected cash outflow (excluding interest expense and land cost) for both the mass timber and reinforced concrete buildings. From Figure 9 it can be seen that the R14 370000 equity is completely exhausted within two months of construction for the timber frame building. Similarly, within two months the R3 796000 equity for the concrete frame building is also exhausted. Interest is effectively charged for four months for the timber frame building and nine months for the concrete frame building. The total interest payable by the developer over the construction period is R1 486200 for the timber frame building. Alternatively, R 2706000 is payable by the developer for interest incurred for the construction of the concrete frame building. The five-month shorter construction schedule results in savings of R1 220000 in interest for the timber frame building.

\section{Internal rate of return}

The feasibility of the two developments can be assessed through the calculation and evaluation of the internal rate of return (IRR) and minimum acceptable rate of return (MARR) of each development. If the IRR is greater than the MARR, the development is financially justifiable (Blank \& Tarquin 2014). When evaluating two different developments, the development with the greatest IRR is the more profitable development from an investor's perspective. The MARR, or hurdle rate, can be assumed to be $15 \%$ for the commercial developments in this study (Abland 2020). The five-year IRR of the developments were calculated through the development of amortisation schedules in the financial model. The mass timber building achieved a five-year IRR of $20.9 \%$, while the reinforced concrete building achieved a five-year IRR of $25.7 \%, 4.8 \%$ higher than the IRR of the mass timber frame building.

From the higher IRR for the reinforced concrete frame development, it is clear 


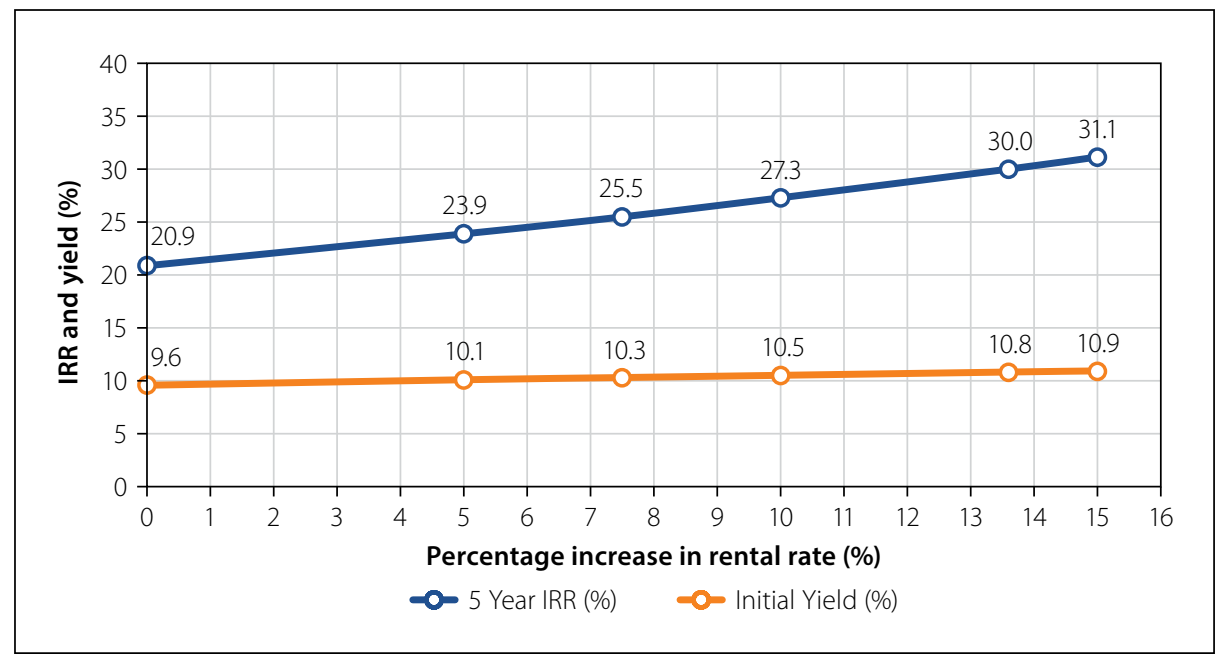

Figure 10 Rental rate analysis for the mass timber frame building

that the concrete alternative remains more profitable than the timber alternative, despite the five-month shorter construction schedule. Notably, the five-year IRR of both developments is above the 15\% MARR, indicating that they are both financially justified. This is a positive result with $100 \%$ assumed occupation for both developments, particularly the multi-storey mass timber building, in the context of South Africa. It indicates that a multi-storey mass timber building can be financially viable in South Africa if a number of factors are addressed throughout the entire value chain of the mass timber products. However, it is evident from this particular comparison - given the assumptions that were made - that mass timber frame commercial buildings will struggle to achieve higher internal rate of returns than conventional reinforced concrete frame commercial buildings.

\section{SENSITIVITY ANALYSIS}

The following section explores the effect of certain variables on the overall construction cost comparison between the two buildings through a sensitivity analysis. The investigation is limited to the variables that have the greatest effect on the overall construction cost of the mass timber frame building.

\section{Rental rate}

It is of interest to explore the effect of a potential rental premium on the mass timber frame building, especially when considering the potential desirability of tenants to work in such a mass timber frame building. The effect of adjusting the rental rate on the fiveyear IRR and initial yield is summarised in Figure 10. The rental rate for the reinforced concrete frame building remained constant at $\mathrm{R} 150 / \mathrm{m}^{2}$ for the entire analysis.
Analysis of the results shows the significant effect of the rental rate on the five-year IRR of the development. A potential $7.8 \%$ increase in rental rate would result in a five-year IRR of $25.7 \%$ for the mass timber frame development. This is equivalent to the $25.7 \%$ IRR recorded for the reinforced concrete frame building. It remains difficult to determine whether a $7.8 \%$ rental premium is justifiable for the mass timber frame development.

\section{Cost of SA pine}

The large difference in the structural frame cost between the two buildings can be partly attributed to the high cost per cubic metre of S7 SA pine. Discussions with manufacturers indicated that it costs approximately $\mathrm{R} 12$ 000/m³ ${ }^{3}$ of S7 SA pine to manufacture glulam or CLT (Holzbau Carpentry Hess CC 2020; XLAM South Africa (Pty) Ltd 2020). It remains difficult to determine how prices may differ in an established multi-storey mass timber market. To this end, fictional market prices of S7 SA pine were investigated. The results are summarised in Table 9.

Table 9 shows that a $5 \%$ decrease in the cost of SA pine results in a R933 606 (4\%) reduction in the overall structural cost of the development. This translates into an increase of approximately $0.7 \%$ in the five-year IRR. Similarly, a $5 \%$ increase in the cost of SA pine results in a $0.7 \%$ decrease in the fiveyear IRR. From this analysis it is clear that fluctuation in the cost of the SA pine has a substantial effect on the five-year IRR of the development, although it is not as sensitive as fluctuation in the rental rate. An increase of $5 \%$ in the rental rate increases the five-year IRR between $3.0 \%$ and $3.8 \%$, which is significantly more than the $0.7 \%$ increase recorded for a decrease of $5 \%$ in the cost of S7 SA pine. Results showed that the price of S7 SA pine needs to be reduced by at least $33 \%$ for the mass timber frame development to earn a higher five-year IRR than the reinforced concrete frame development. This is considered to be highly unlikely.

\section{Importation of timber}

The section above dealing with "Development cost" (commencing on page 40) alludes to the fact that the importation of structural timber will have to be considered for the immediate future to sustain a potential multi-storey mass timber building market. As such, an analysis of the potential structural cost and five-year IRR of the development is required if all of the mass timber is imported. Table 10 contains the results of the analysis. The results of the analysis are based on the cost of untreated spruce as calculated in the aforementioned section on "Development cost".

At a R17:€1 exchange rate, the total structural cost increases from R23 285000 for the original S7 SA pine option to R30 255000 for imported spruce. This amounts to a $30 \%$ increase in the total structural cost of the building. Additionally, it results in a $4.5 \%$ decrease in the five-year IRR from $20.9 \%$ to $16.4 \%$. In the section above dealing with "Internal rate of return" (page 42), a 25.7\% IRR is calculated for the reinforced concrete frame development.
Table 9 Analysis of S7 SA pine cost

\begin{tabular}{|c|c|c|}
\hline $\begin{array}{c}\text { Change } \\
\text { (SA pine) }\end{array}$ & $\begin{array}{c}\text { SA pine cost } \\
\left(\mathbf{R} / \mathbf{m}^{\mathbf{3}}\right)\end{array}$ & $\begin{array}{c}\text { Structural } \\
\text { cost (R) }\end{array}$ \\
\hline$+15 \%$ & 13800 & 26074029 \\
\hline$+10 \%$ & 13200 & 25140423 \\
\hline$+5 \%$ & 12600 & 24206817 \\
\hline $0 \%$ & 12000 & 23284732 \\
\hline$-5 \%$ & 11400 & 22339606 \\
\hline$-10 \%$ & 10800 & 21406000 \\
\hline$-15 \%$ & 10200 & 20472394 \\
\hline
\end{tabular}

\begin{tabular}{|c|}
\hline Difference (R) \\
\hline 933606 \\
\hline 933606 \\
\hline 933606 \\
\hline 0 \\
\hline-933606 \\
\hline-933606 \\
\hline-933606 \\
\hline
\end{tabular}

IRR (\%)

$18.9 \%$

$19.5 \%$

$20.2 \%$

$20.9 \%$

$21.6 \%$

$22.3 \%$

$23.1 \%$ 


\begin{tabular}{|c|c|c|c|c|}
\hline Exchange rate & $\begin{array}{l}\text { Spruce glulam } \\
\text { cost }\left(\mathrm{R} / \mathrm{m}^{3}\right)^{*}\end{array}$ & $\begin{array}{l}\text { Spruce CLT } \\
\text { cost }\left(\mathrm{R} / \mathrm{m}^{2}\right)^{*}\end{array}$ & $\begin{array}{c}\text { Structural } \\
\text { cost }(\mathrm{R})\end{array}$ & $\begin{array}{c}\text { Five-year } \\
\text { IRR (\%) }\end{array}$ \\
\hline R19:€1 & 17602 & 3968 & 32520480 & 15.2 \\
\hline R18:€1 & 16733 & 3816 & 31387958 & 15.8 \\
\hline $\mathrm{R} 17: € 1$ & 15863 & 3664 & 30255437 & 16.4 \\
\hline R16:€1 & 14994 & 3512 & 29122915 & 17.0 \\
\hline R15:€1 & 14124 & 3360 & 27990393 & 17.7 \\
\hline
\end{tabular}

This is $9.3 \%$ higher than the $16.4 \%$ calculated for the imported mass timber frame.

The assumption regarding the locally produced mass timber elements should be taken into consideration. The manufacturing capabilities of local suppliers, as discussed earlier, remains a concern. As such, a fictional situation was assumed where South African suppliers can manufacture the large cross-sectional dimensions required for the mass timber frame building in this research. Without this assumption, the timber would most likely need to be imported unless current manufacturing capabilities improve.

\section{CONCLUSION}

The findings of this study show that there is great potential in the multi-storey mass timber building domain in South Africa. This is justified by the $50 \%$ reduction in the construction schedule for the mass timber frame building, but also by the sensitivity analysis where the mass timber frame building achieved the same five-year IRR than the reinforced concrete building with a $7.8 \%$ rental premium. However, it has become evident through interaction with various industry stakeholders that great strides are still required in the forestry sector, mass timber manufacturing sector, as well as the AEC sector before multi-storey commercial mass timber buildings may prove to be more profitable than conventional multi-storey reinforced concrete buildings in South Africa.

Two of the most notable requirements include improvement in the sourcing of high-grade structural timber (S7, S10) and investment into equipment that will enable the large-scale production of large beams/columns, typically required in multi-storey mass timber structures. Development and investment of capital and resources are required throughout the entire value chain of mass timber production to establish a sustainable multi-storey mass timber market.
The future success of mass timber construction in South Africa is thus dependent on the collaboration and teamwork of industry stakeholders and research institutions throughout the public and private domain.

\section{REFERENCES}

Abland 2020. Abland (Pty) Ltd 2020 online interview,

1 June, Johannesburg.

Arup 2019. Rethinking timber buildings. https://www. arup.com/perspectives/publications/research/ section/rethinking-timber-buildings.

Anderson, J E, Wulfhorst, G \& Lang, W 2015. Energy analysis of the built environment: A review and outlook. Renewable and Sustainable Energy Reviews, 44: 149-158. doi: 10.1016/j.rser.2014.12.027.

Autodesk 2019. Revit (Version 2019.2.1) [Computer

Program]. Autodesk, San Rafael, CA.

Blank, L \& Tarquin, A 2014. Rate of Return analysis. In: Basics of Engineering Economy. 2nd ed. New York: McGraw Hill, 143

Crafford, P L \& Wessels, C B2020. South African log resource availability and potential environmental impact of timber construction. South African Journal of Science, 116(7/8): 1-8. doi: 10.17159/sajs.2020/6419.

Drennan, M B 2017. Comparative construction costs of typical low-rise office buildings in South Africa.

Master's Thesis. University of Stellenbosch.

EN (European Standard) 2004. EN 1995-1-1: Eurocode

5: Design of Timber Structures. Brussels, European Committee for Standardization (CEN).

Forestry Innovation Investment Ltd (FII) 2017. Brock Commons Tallwood House, Naturally Wood. Vancouver, Canada: FII. https:// www.naturallywood.com/wp-content/ uploads/2020/08/brock-commons-tallwoodhouse_factsheet_naturallywood.pdf. Holzbau Carpentry Hess CC 2020. Online interview, 5 May, Stellenbosch.

MGA/Michael Green Architecture 2012. The Case for Tall Wood Buildings, 2nd ed. Vancouver, Canada, p 240. http://cwc.ca/wp-content/uploads/

Petersen, A K \& Solberg, B 2005. Environmental and economic impacts of substitution between wood products and alternative materials: A review of publications-Tall-Wood.pdf. micro-level analyses from Norway and Sweden. Forest Policy and Economics, 7(3): 249-259. http://linkinghub.elsevier.com/retrieve/pii/ S1389934103000637.

Salvadori, V 2017. The development of a tallwood building. Master's Thesis. Vienna, Austria:

Politecnico Milano \& Technische Universitat Wien (TU Wien).

SANS 2000. SANS 10100-1: 2000: The Structural Use of Concrete, Edition 2.2. Pretoria: SABS Standards Division.

SANS 2003. SANS 10163-1:2003: Structural Use of Timber. Part 1: Limit-states Design, Edition 2.3. Pretoria: SABS Standards Division.

SANS (South African National Standard) 2011. SANS 10160-2 2011: Basis of Structural Design and Actions for Buildings and Industrial Structures. Part 2: Self Weight and Imposed Loads, Edition 1.1. Pretoria: SABS Standards Division.

SANS 2020. SANS 10005: 2020: The Preservative Treatment of Timber. Edition 9. Pretoria: SABS Standards Division.

Sathre, R \& O'Connor, J 2010. Meta-analysis of greenhouse gas displacement factors of wood product substitution. Environmental Science \& Policy, 13(2): 104-114. http://linkinghub.elsevier. com/retrieve/pii/S1462901109001804.

Smith, R E, Griffin, G, Rice, T \& Hagehoffer-Daniell, B 2018. Mass timber: evaluating construction performance. Architectural Engineering and Design Management, 1(1-2): 27-138. doi/abs/10.1080/17420 07.2016.1273089.

Stora Enso 2019. Calculatis (Version 2019). [Computer Program]. Helsinki, Finland. https://www.storaenso. com/en/products/wood-products/calculatis.

Timber Development Association NSW 2015. Rethinking Apartment Building Construction Consider Timber. Melbourne: Forest and Wood Products Australia.

Upton, B, Miner, R, Spinney, M \& Heath, L S 2008. The greenhouse gas and energy impacts of using wood instead of alternatives in residential construction in the United States. Biomass and Bioenergy, 32(1): 1-10. http://www.sciencedirect.com/ science/article/pii/S0961953407001109. UN Habitat 2016. World Cities Report 2016 Urbanization and Development: Emerging Futures. https://unhabitat.org/world-cities-report.

Wang, L, Toppinen, A \& Juslin, H 2014. Use of wood in green building: A study of expert perspectives from the UK. Journal of Cleaner Production, 65: 350-361. http://linkinghub.elsevier.com/retrieve/pii/ S0959652613005623.

Werner, F \& Richter, K 2007. Wooden building products in comparative LCA: A literature review. International Journal of Life Cycle Assessment, 12(7): 470-479.

XLAM South Africa (Pty) Ltd 2020. Online interview, 5 May, Stellenbosch. 